\title{
MiR-744 facilitates non-small cell lung cancer progression by direct transcriptional regulation and indirect MAPK pathway activation mediated upregulation of C-FOS
}

Xiaoxia Zhu ( $\nabla$ zhuxx01@126.com )

Zhujiang Hospital, Southern Medical University

Shangbiao Li

Zhujiang Hospital, Southern Medical University

$\mathrm{Na} \mathrm{Li}$

Zhujiang Hospital, Southern Medical University

\section{Research}

Keywords: microRNA-744, C-FOS, NSCLC, MAPK.

Posted Date: August 25th, 2020

DOl: https://doi.org/10.21203/rs.3.rs-63976/v1

License: (c) (i) This work is licensed under a Creative Commons Attribution 4.0 International License. Read

Full License 


\section{Abstract}

Background: Metastasis is the leading cause of lung cancer associated death. Here, we focused on the function and molecular mechanism of miR-744 and its potential clinical application in lung carcinoma.

Methods: The clinical cohort and data from TCGA were analyzed for the correlation of miR-744 and outcomes. Multiple NSCLC cell lines and a xenograft model were applied for the functional studies. Reporter assays were explored for transcriptional regulatory mechanism.

Results: It was confirmed that the overexpression of miR-744 was significantly correlated with lymph node metastasis and poor prognosis in NSCLC. Both in vitro and in vivo studies revealed that miR-744 overexpression aggravated the growth, invasion and metastasis of NSCLC cells. MiR-744 enhanced the resistance of lung cancer cells to radiotherapy and paclitaxel. MiR-744 positively regulated C-FOS by directly binding to the promoter of C-FOS and -1195 to -1227 and -298 to -323 bp upstream of C-FOS gene were the direct and efficient miR-744 binding sites. MiR-744 could also indirectly upregulate c-FOS protein by activating MAPK pathway.

Conclusion: Our findings uncover the function and a novel mechanism of miR-744 in mediating growth and metastasis of NSCLC cells. Our data suggests that miR-744 may serve as a possible therapeutic target for NSCLC.

\section{Introduction}

Despite recent advances in diagnostic and therapeutic measures, survival improvement is still a serious challenge in lung cancer[1]. Although various driven gene targets have been reported, less than $50 \%$ of lung cancer would benefit from these drugs. To date, however, promising molecular genetic alterations with clinical or prognostic significance in lung cancer have remained elusive. Therefore, it is necessary to further clarify the underlying molecular mechanisms and to identify specific biomarkers or targets of lung cancer.

Intensive researches in past two decades have uncovered the presence and importance of miRNAs in human carcinogenesis[2]. In our previous miRNA microarray analysis, we demonstrated for the first time that the expression of miR-744 was decreased significantly by metastasis associated gene 1(MTA1) knockdown[3] in non-small cell lung cancer (NSCLC). Meanwhile, we also verified the oncogenic potential of miR-744 in nasopharyngeal carcinoma tumorigenesis and metastasis[4]. Above results provided new insights into the molecular mechanisms underlying carcinogenesis and indicated the possibly essential role of miR-744 in tumor development. But little is known about the expression, exact biologic functions and mechanisms of miR-744 in NSCLC. Here, we demonstrate that miR-744 is significantly overexpressed in lung cancer and associated with a poor prognosis. MiR-744 can promote lung cancer cells growth, invasion and metastasis both in vitro and in vivo. It also can increase the resistance of lung cancer cells to paclitaxel and radiation.

C-FOS, defined as an oncogene, plays a critical role in the tumorigenesis[5], and a better understanding of the epigenetic regulation of C-FOS is crucial. Importantly, we provide evidence for the first time that miR-744 
is a positive regulator of C-FOS by directly binding to its promoter region in lung cancer. Interestingly, we found that miR-744 could upregulate C-FOS protein level by activating the MAPK pathway and consequently enhanced the malignant phenotype of lung cancer cells. Our data first demonstrated the regulatory mechanism of oncogene C-FOS by miR-744 at the level of transcription, which partly explained the proto-oncogene role of miR-744 in NSCLC.

\section{Materials And Methods}

\section{Cell lines and clinical samples}

The human lung cancer cell lines A549, H520 were obtained from ATCC (Manassas, VA), the H1299, SPC-A1 cells and immortalized lung epithelial cell line HBE were purchased from Shanghai Cell Bank of Chinese Academy of Science (Shanghai, China). All cell lines were cultured in RPMI-1640 medium (Corning, NY, USA) containing $10 \%$ fetal bovine serum (FBS, GIBCO, South America, NY, USA) under a $5 \% \mathrm{CO}_{2}$ atmosphere at $37^{\circ} \mathrm{C} .15$ matched non-small cell lung cancer (NSCLC) tissues and their adjacent noncancerous tissues (NCTs) were collected from Nanfang Hospital and stored in liquid nitrogen. All of the human samples were obtained with informed consents and histologically confirmed by hematoxylin and eosin (H\&E) staining. This study project was approved by the Clinical Research Ethics Committee of Nanfang Hospital. Tissue chips consisted of 87 cases of human NSCLC were acquired from Outdo Biotech CO. Ltd. (Shanghai, China). The clinical pathological characteristics of 87 patients and 456 patients with NSCLC from The Cancer Genome Atlas (TCGA) were summarized in Supplementary Table 1 and Table 2.

\section{In Situ Hybridization (ISH)}

ISH experiments was performed according to the protocol described previously[6]. Briefly, probes for miR744, positive control (U6) and negative control were purchased from Exiqon, Vedbek, Denmark. The intensity of cytoplasmic staining was scored manually semiquantitatively. The dominant staining intensity in tumor cells was scored as (S1 Fig): 0 = negative; 1 = weak; 2 = moderate; $3=$ strong. A score of 3 was considered as high miR-744 expression and $<3$ as low miR-744 expression.

\section{Construction and stable transfection of lentivirus vector}

The precursor sequence of miR-744 (MI0005559) was synthesized, annealed and then inserted into the Agel/EcoR1 site of GV209 vector (GeneChem, Shanghai, China) to construct a vector continuously expressing miR-744, named as LV-miR-744. The GFP vector was used for control. PLV-Luci-control was also constructed by GeneChem (Shanghai, China). A549 and H520 cells were co-transfected with Lv-miR-744 or Lv-control vector and pLV-Luci-control. The clones with GFP expression were isolated under puromycin $(2 \mathrm{mg} / \mathrm{mL})$ selection for 2 weeks.

\section{Plasmid construction and transient transfection}

AntagomiR744, antagomir negative control (antagomir-NC), agomiR744, agomir negative control (agomirNC) were designed and synthesized by RiboBio (Guangzhou, China). Sic-FOS and sicontrol were designed and synthesized by Genepharma (Shanghai, China). The cells were seeded in 6-well plates at $30-50 \%$ density. Transient transfection was performed with Lipofectamine 3000 reagents according to the 
manufacturer's instructions (Invitrogen, USA). For all the experiments, cells were collected at $48 \mathrm{~h}$ after transfection for further research.

\section{RNA extraction and quantitative real-time PCR (qRT-PCR) analyses}

Total RNA was extracted from cell lines using TRIzol® Reagent (Invitrogen, CA, USA) according to the manufacturer's instruction. The reverse transcription of RNA for miR-744 and c-FOS mRNA was performed using SYBR ${ }^{8}$ PrimeScript ${ }^{\text {Tm }}$ miRNA RT-PCR Kit (TaKaRa, Dalian, China) and PrimeScript ${ }^{\text {Tm }}$ RT reagent Kit (TaKaRa, Dalian, China) separately. The real-time quantitative RT-PCR assay was carried on a Mx3005P

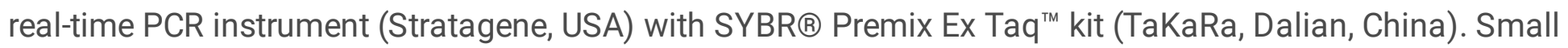
nuclear RNA U6 (U6 snRNA) or Glyceraldehyde-3-phosphate dehydrogenase (GAPDH) was used as an internal control for miRNA or mRNA quantification respectively. The sequences of the primers used for qRTPCR were listed in Supplementary Table 3.

\section{Western Blot}

Equal amounts of harvested proteins were first separated by $10 \%$ SDS-PAGE gels and then transferred to nitrocellulose membranes (Immobilon-P, Merck Millipore, Germany). The membranes were blocked with 5\% nonfat milk and incubated with primary antibodies against GRB2, Raf1, Erk, p-Erk, c-FOS (1:2000, Abcam, Cambridge, USA) and GAPDH (1:2000, Santa Cruz Biotechnology, CA, USA) respectively at $4{ }^{\circ} \mathrm{C}$ overnight, and subsequently incubated for $2 \mathrm{~h}$ with horseradish peroxidase-conjugated goat anti-mouse secondary antibody (1:5000; Santa Cruz Biotechnology, CA, USA) at room temperature. The protein complex was detected using enhanced chemiluminescence reagents (Immobilon Western, Merck Millipore, Germany). Endogenous $\beta$-Actin protein was used as internal control.

\section{Microarray analysis}

Followed by RNA extraction with TRIzol reagent, cells transfected with antagomiR-744 or antagomir-NC

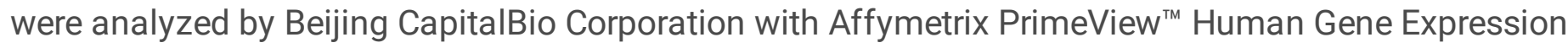
Array.

\section{EdU assay}

After transfection for $48 \mathrm{~h}$, cells were used to measure DNA synthesis with a CellLight ${ }^{\text {TM }}$ EdU imaging detecting kit (RiboBio, Guangzhou, China) according to the manufacturer's instructions.

\section{CCK8 cell assay}

After transfection, the cells were seeded in $96-$ well plates (5000 per well). After the cells were attached to the culture dish, paclitaxel was added to each well with the following concentration gradients (0$16 \mathrm{nmol} / \mathrm{L}$ or $0-32 \mathrm{nmol} / \mathrm{L}) .10 \mu \mathrm{l} \mathrm{CCK} 8$ was added into each well after $78 \mathrm{~h}$ and was incubated for $2 \mathrm{~h}$. The absorbance values (OD) were measured at a wavelength of $450 \mathrm{~nm}$ using a microplate reader.

\section{Colony formation assay}

The cells were seeded at a density of 200-10000 cells/well in a 6-well plate. The cells were irradiated with different doses (0, 2, 4, 6 and $8 \mathrm{~Gy}$ ) of X-rays. After 10 days incubation in RPMI-1640 medium with 20\% FBS at $37^{\circ} \mathrm{C}, 5 \% \mathrm{CO}_{2}$, the cells were fixed in $4 \%$ paraformaldehyde and stained with $0.5 \%$ crystal violet in $20 \%$ 
methanol. The colonies were counted. The survival curves were fitted by a linear-quadratic model [S = exp ($\left.a D-\beta D^{2}\right)$ ] using GraphPad Prism 5.0 (GraphPad Prism, San Diego, CA, USA).

\section{Cell migration and invasion assays}

Cell invasion assay was performed using Transwell chamber (Corning, NY, USA) in a 24-well plate. Transfected cells $\left(5-10 \times 10^{4}\right.$ cells per $\left.100 \mu \mathrm{l}\right)$ in serum-free medium were seeded into the upper chamber with $12.5 \%$ matrigel-coated membrane (BD Bioscience, San Jose, CA), while the lower chamber was filled with $500 \mu \mathrm{l}$ fresh complete medium. After being incubated for $18-24 \mathrm{~h}$ at $37^{\circ} \mathrm{C}$ with $5 \% \mathrm{CO} 2$, non-invading cells were removed from the upper surface of the filter by wet cotton swab. Invading cells that adhered to the lower surface of the chambers were fixed in methyl alcohol and stained with hematoxylin. The invading cells were manually counted at $200 \times$ magnification under a inverted microscope. Five visual fields of each chamber were randomly chosen and photographed. Similar upper inserts without the matrigel precoating were used for the migration assay.

\section{Wound healing assay}

As described in previous study[4],when cells were grown to approximately $90 \%$ confluency (after $48 \mathrm{~h}$ of transfection), an artificial wound was created with a $10 \mu$ pipette tip. The cells were then cultured in fresh medium without FBS. To visualize wound healing, images were taken at $0 \mathrm{~h}$ and $36 \mathrm{~h}$. The relative percentage of wound healed was calculated as (the width of wound at $0 \mathrm{~h}$ - the width of wound at $36 \mathrm{~h}$ )/the width of wound at $0 \mathrm{~h}$.

\section{Promoter reporter construction and luciferase assays}

The pGL3 vectors containing human c-FOS promoter with wild type or mutant putative miR-744 binding site were synthesized and confirmed with DNA sequencing by HuaAnPingKang Co., Ltd (Shenzhen, China). The sequences of these wild type or mutant promoter constructs were listed in Supplementary Table 4-7. The cells were plated onto 24-well plates at a density of $5 \times 10^{3}$ cells/well for transfection study. A mixture of 150 ng c-FOS promoter constructs (Luc-C-FOS-A, Luc-C-FOS-B, Luc-C-FOS-C, Luc-C-FOS ${ }^{\text {mut-1 }}$, Luc-CFOS $^{\text {mut-2 }}$, Luc-C-FOS ${ }^{\text {mut-3 }}$, Luc-C-FOS ${ }^{\text {mut-4 }}$ ) or responding control vectors, $100 \mathrm{nmol}$ agomiR744 or agomir negative control (agoNC) and $5 \mathrm{ng}$ pRL-TK vector (Promega, WI, USA) were co-transfected into cells for each well using Lipofectamine 3000, and then incubating for 48 hours. Dual luciferase reporter assay system (Promega, WI, USA) was used to perform the luciferase assay according to the manufacturer's instruction.

\section{Xenograft tumor growth assay}

Fourtosix weeks old athymic male BALB/c nude mice were purchased from the Guangdong Medical Laboratory Animal Center (GDMLAC, Foshan, China), and were group-housed under specific pathogen-free (SPF) conditions. The experimental protocols were approved by the Institutional Animal Care and Use Committee at our University. A549 or H520 cells stably overexpressing miR744 or the control vector $\left(8 \times 10^{5}\right.$ cells) were injected subcutaneously into the dorsal flank of mice ( $n=5$ per group). A549 or $\mathrm{H} 520$ cells, transfected with antagomiR-744 or antagomir-NC, were also used for xenograft experiments following the procedures described above. After 8 days of implantation of tumor cells, tumor size was measured every 3 
days and tumor volumes were calculated with the following formula: $V=\left(L \times W^{2}\right) / 2$, where $L$ is the length and $W$ is the width of each tumor. At the end of experiments (about after 4-6 weeks), the mice were sacrificed and tumors were dissected and weighed.

\section{In vivo metastasis assay}

A549 or H520 cells $\left(2 \times 10^{6}\right)$ stably overexpressing miR744 or NC were injected into the tail veins of BALB/C nude mice ( $n=5$ per group). After 30 days, the lung colonization capacity of the cancer cells was analyzed based on the normalized bioluminescence imaging. Then the mice were sacrificed and the lung tissues were dissected and fixed in $4 \%$ formaldehyde overnight. The fixed samples were embedded in paraffin and stained with hematoxylin and eosin (HE). Lung metastasis index was calculated as our previous study described[4]: metastatic tumor areas/total lung areas.

\section{Statistical analysis}

Statistical analyses were performed using GraphPad Prism 6.0 (GraphPad Software, San Diego, CA, USA) and SPSS 13.0 (SPSS Inc., Chicago, USA). Each experiment was repeated at least three times and data were expressed as the mean \pm SE. Two-tailed unpaired Student's independent samples ttest was used to assess differences among groups in in vitro or in vivo studies. Brown-Forsythe method was used for the relative mRNA expression of each cell lines. Spearman's correlation was used to analyze the relationship between miR744 and c-FOS mRNA expression. Kaplan Meier survival analysis and cox regression were performed to calculate overall survival (OS) and estimate the prognostic factors. P value $<0.05$ was considered statistically, and ${ }^{*} p<0.05,{ }^{*} \mathrm{p}<0.01,{ }^{\star \star \star} \mathrm{p}<0.001$.

\section{Results}

\section{MiR-744 is up-regulated in NSCLC and associated with poor clinical outcome}

We first detected the expression of miR-744 in 15 matched NSCLC tissues and their adjacent tissues and found that miR-744 was up-regulated in cancer tissues (Fig. 1A). MiR-744 expression was then quantified in 87 formalin-fixed paraffin-embedded (FFPE) NSCLC tissues (training set) and 456 primary NSCLC from TCGA (validation set). Notably, miR-744 expression was significantly associated with lymph node metastasis (S1-S2 Table). Survival analyses revealed that patients with higher level of miR-744 presented shorter OS (Fig. 1B,training set: $p=0.005$; validation set: $p=0.002$ ). The multivariate Cox regression analyses in two cohorts both indicated that higher expression of miR-744 is an independent unfavorable prognostic marker for OS (S8-S9 Table, training set: HR 2.294 [1.063-4.949], $p=0.034$; validation set: HR 2.093 [1.386-3.160], $p=0.000$ ). Subgroup analysis in validation set also showed that higher expression of miR-744 was especially associated with worse OS among male group (median 38.5 vs 88.0 months, $p=$ 0.001 ), over-60 age group (median 38.5 vs 71.1 months, $p=0.000$ ), SCC group (median 35.6 vs 64.4 months, $p=0.001$ ), T1/T2 group (median 41.9 vs 72.3 months, $p=0.005$ ), and N0/N1 group (median 44.9 vs 66.4 months, $p=0.009$ ) (S2 Fig). Furthermore, compared with HBE, miR-744 was up-regulated in most of NSCLC cell lines (Fig. 1C). 
Table 1

A brief summary of researches on miR-744 in different types of tumor.

\begin{tabular}{|c|c|c|c|c|c|}
\hline Tumor types & Sample types & $\begin{array}{l}\text { Oncogene(+)/ } \\
\text { Tumor } \\
\text { suppressor } \\
\text { gene(-) }\end{array}$ & Functions & Mechanisms & References \\
\hline $\begin{array}{l}\text { Sporadic } \\
\text { vestibular } \\
\text { schwannomas }\end{array}$ & Tumor tissues & $(-)$ & Growth & - & [7] \\
\hline $\begin{array}{l}\text { Chronic } \\
\text { Lymphocytic } \\
\text { Leukemia }\end{array}$ & $\begin{array}{l}\text { Mononuclear } \\
\text { cells }\end{array}$ & $(-)$ & Prognosis & - & [8] \\
\hline \multirow[t]{2}{*}{$\begin{array}{l}\text { Colorectal } \\
\text { cancer }\end{array}$} & $\begin{array}{l}\text { Tumor tissues } \\
\text { and cell lines }\end{array}$ & $(+)$ & Chemoresistance & BIN1 3'UTR & [9] \\
\hline & & $(-)$ & $\begin{array}{l}\text { Proliferation, } \\
\text { invasion }\end{array}$ & Notch1 & [10] \\
\hline \multirow[t]{3}{*}{$\begin{array}{l}\text { Hepatocellular } \\
\text { carcinoma }\end{array}$} & $\begin{array}{l}\text { Tumor tissues, } \\
\text { cell lines, } \\
\text { serum } \\
\text { exosomes }\end{array}$ & $(-)$ & $\begin{array}{l}\text { Proliferation, } \\
\text { sorafenib } \\
\text { resistance }\end{array}$ & PAX2 & [11] \\
\hline & Tumor tissues & $(-)$ & Prognosis & - & [12] \\
\hline & $\begin{array}{l}\text { Tumor tissues, } \\
\text { cell lines }\end{array}$ & $(-)$ & Proliferation & c-Myc 3'UTR & [13] \\
\hline \multirow[t]{4}{*}{ NSCLC } & Cell lines & $(-)$ & $\begin{array}{l}\text { Proliferation, } \\
\text { invasion }\end{array}$ & PAX2 3'UTR & [14] \\
\hline & & $(-)$ & - & RING1 & [15] \\
\hline & & $(-)$ & - & MAFG & [16] \\
\hline & Plasma & $(-)$ & $\begin{array}{l}\text { Primary } \\
\text { resistance to TKI }\end{array}$ & - & [17] \\
\hline \multirow[t]{2}{*}{ Osarcoteosma } & $\begin{array}{l}\text { Tumor tissues } \\
\text { and cell lines }\end{array}$ & $(+)$ & $\begin{array}{l}\text { Prognosis, } \\
\text { proliferation, } \\
\text { migration, } \\
\text { invasion }\end{array}$ & $\begin{array}{l}\text { LATS2 } \\
\text { 3'UTR } \\
\text { Wnt/ß- } \\
\text { catenin } \\
\text { pathway }\end{array}$ & [18] \\
\hline & & & & EMT & \\
\hline
\end{tabular}

Abbreviation: BIN1, Bridging integrator 1; PAX2, Paired box 2; LATS2, large tumor suppressor kinase 2; EMT, epithelial-mesenchymal transition; MAFG, MAF bZIP transcription factor G; ACO2, Aconitase 2; LKB1, liver kinase B1; AMPK, adenosine monophosphate-activated protein kinase; NOB1, NIN1/RPN12 binding protein1 homolog; TGFB1, Transforming Growth Factor Beta 1; DVL2, Dishevelled2; ARHGAP5, Rho GTPase activating protein 5; Bcl-2, B cell lymphoma 2; NFIX, Nuclear factor I X; HNRNPC, Heterogeneous nuclear ribonucleoprotein C; SFRP1, secreted frizzled-related protein 1 ; GSK3 $\beta$, glycogen synthase kinase 3ß; TLE3, transducin-like enhancer of split 3; Ccnb1, Cyclin B1. 


\begin{tabular}{|c|c|c|c|c|c|}
\hline Tumor types & Sample types & $\begin{array}{l}\text { Oncogene(+)/ } \\
\text { Tumor } \\
\text { suppressor } \\
\text { gene(-) }\end{array}$ & Functions & Mechanisms & References \\
\hline \multirow[t]{3}{*}{$\begin{array}{l}\text { Pancreatic } \\
\text { cancer }\end{array}$} & $\begin{array}{l}\text { Bioinformatics } \\
\text { analysis }\end{array}$ & $(+)$ & Prognosis & - & [19] \\
\hline & $\begin{array}{l}\text { Plasma, cell } \\
\text { lines }\end{array}$ & $(+)$ & $\begin{array}{l}\text { Prognosis, } \\
\text { Chemoresistance }\end{array}$ & - & [20] \\
\hline & $\begin{array}{l}\text { Tumor tissues, } \\
\text { cell lines, } \\
\text { animals }\end{array}$ & $(+)$ & $\begin{array}{l}\text { Prognosis, stem } \\
\text { cell-like } \\
\text { phenotype } \\
\text { growth }\end{array}$ & $\begin{array}{l}\text { SFRP1 } \\
\text { 3'UTR } \\
\text { GSK3 } \beta \\
\text { 3'UTR TLE3 } \\
\text { 3'UTR }\end{array}$ & [21] \\
\hline $\begin{array}{l}\text { Pituitary } \\
\text { oncocytoma }\end{array}$ & $\begin{array}{l}\text { Tumor tissues } \\
\text { and cell lines }\end{array}$ & $(-)$ & Proliferation & ACO2 3'UTR & [22] \\
\hline \multirow[t]{5}{*}{ Prostate cancer } & \multirow{2}{*}{$\begin{array}{l}\text { Tumor tissues } \\
\text { and cell lines }\end{array}$} & \multirow[t]{2}{*}{$(+)$} & \multirow{2}{*}{$\begin{array}{l}\text { Prognosis, } \\
\text { proliferation }\end{array}$} & LKB1 3'UTR & [23] \\
\hline & & & & $\begin{array}{l}\text { AMPK } \\
\text { signaling } \\
\text { pathway }\end{array}$ & \\
\hline & \multirow{2}{*}{$\begin{array}{l}\text { Tumor tissues, } \\
\text { cell lines, } \\
\text { animals }\end{array}$} & \multirow[t]{2}{*}{$(+)$} & \multirow{2}{*}{$\begin{array}{l}\text { Prognosis, } \\
\text { proliferation, } \\
\text { migration, } \\
\text { invasion }\end{array}$} & NKD1 3'UTR & [24] \\
\hline & & & & $\begin{array}{l}\text { Wnt/ } \beta- \\
\text { catenin } \\
\text { pathway }\end{array}$ & \\
\hline & $\begin{array}{l}\text { Cell lines, } \\
\text { animals }\end{array}$ & $(+)$ & Proliferation & $\begin{array}{l}\text { Ccnb1 } \\
\text { promoter }\end{array}$ & [25] \\
\hline \multirow[t]{2}{*}{ Glioblastoma } & $\begin{array}{l}\text { Tumor tissues, } \\
\text { cell lines, } \\
\text { animals }\end{array}$ & $(-)$ & $\begin{array}{l}\text { Proliferation, } \\
\text { migration, and } \\
\text { invasion }\end{array}$ & NOB1 3'UTR & [26] \\
\hline & $\begin{array}{l}\text { Tumor tissues, } \\
\text { cell lines }\end{array}$ & $(-)$ & Migration & $\begin{array}{l}\text { TGFB1 } \\
\text { 3'UTR, DVL2 } \\
\text { 3'UTR }\end{array}$ & [27] \\
\hline \multirow[t]{2}{*}{ Cervical cancer } & Cell lines & $(+)$ & $\begin{array}{l}\text { Migration and } \\
\text { invasion }\end{array}$ & $\begin{array}{l}\text { ARHGAP5 } \\
\text { promoter }\end{array}$ & [28] \\
\hline & Cell lines & $(-)$ & Chemoresistance & - & [29] \\
\hline Gastric cancer & $\begin{array}{l}\text { Tumor tissues, } \\
\text { cell lines }\end{array}$ & $(-)$ & Proliferation & BCL2 3'UTR & [30] \\
\hline
\end{tabular}

Abbreviation: BIN1, Bridging integrator 1; PAX2, Paired box 2; LATS2, large tumor suppressor kinase 2; EMT, epithelial-mesenchymal transition; MAFG, MAF bZIP transcription factor G; ACO2, Aconitase 2; LKB1, liver kinase B1; AMPK, adenosine monophosphate-activated protein kinase; NOB1, NIN1/RPN12 binding protein1 homolog; TGFB1, Transforming Growth Factor Beta 1; DVL2, Dishevelled2; ARHGAP5, Rho GTPase activating protein 5; Bcl-2, B cell lymphoma 2; NFIX, Nuclear factor I X; HNRNPC, Heterogeneous nuclear ribonucleoprotein C; SFRP1, secreted frizzled-related protein 1 ; GSK3 $\beta$, glycogen synthase kinase 3ß; TLE3, transducin-like enhancer of split 3; Ccnb1, Cyclin B1. 


\begin{tabular}{|c|c|c|c|c|c|}
\hline \multirow[t]{2}{*}{ Tumor types } & Sample types & $\begin{array}{l}\text { Oncogene(+)/ } \\
\text { Tumor } \\
\text { suppressor } \\
\text { gene(-) }\end{array}$ & Functions & Mechanisms & References \\
\hline & Serum & $(+)$ & Early detection & - & [31] \\
\hline \multirow[t]{2}{*}{ Ovarian cancer } & Cell lines & $(-)$ & Apoptosis & NFIX 3'UTR, & [32] \\
\hline & & & & $\begin{array}{l}\text { HNRNPC } \\
\text { 3'UTR }\end{array}$ & \\
\hline \multirow[t]{3}{*}{ Breast cancer } & Tumor tissues & $(+)$ & Chemoresistance & - & [33] \\
\hline & $\begin{array}{l}\text { Her2 + tumor } \\
\text { tissues }\end{array}$ & $(-)$ & Proliferation & - & [34] \\
\hline & Cell lines & $(-)$ & Proliferation & $\begin{array}{l}\text { eEF1A2 } \\
\text { 3'UTR }\end{array}$ & [35] \\
\hline \multirow{3}{*}{$\begin{array}{l}\text { Nasopharyngeal } \\
\text { carcinoma }\end{array}$} & Serum & $(+)$ & Prognosis & - & [36] \\
\hline & $\begin{array}{l}\text { Tumor tissues, } \\
\text { cell lines, } \\
\text { animals }\end{array}$ & $(+)$ & $\begin{array}{l}\text { Proliferation, } \\
\text { migration, } \\
\text { invasion }\end{array}$ & $\begin{array}{l}\text { ARHGAP5 } \\
\text { promoter }\end{array}$ & [4] \\
\hline & & & $\begin{array}{l}\text { growth, } \\
\text { metastasis }\end{array}$ & & \\
\hline \multicolumn{6}{|c|}{ 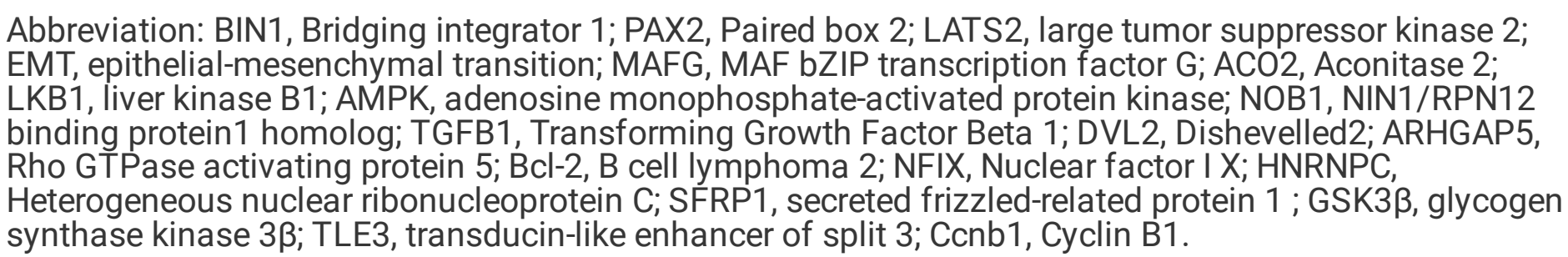 } \\
\hline
\end{tabular}

\section{MiR-744 enhances NSCLC cells malignant phenotype and radio/chemoresistance in vitro}

To investigate the biological functions of miR744 in the development and progression of lung cancer, we next performed gain and lossoffunction studies in lung cancer cells lines by transient transfection with miR-744 agomir or antagomir (Fig. 2A). We found that overexpression of miR744 remarkably increased the proliferative, migrative and invasive ability of lung cancer cell lines, while knockdown endogenous miR-744 had the opposite effect (Fig. 2B-2D and S3 Fig).

To investigate the effect of miR-744 on the sensitivity of NSCLC cells to paclitaxel and radiation, A549 and H520 cell lines were transfected with agomiR744 or antagomiR-744 or corresponding control to perform CCK8 assay and colony formation assay. Cell viability assays indicated that knockdown of miR-744 could improve the response to paclitaxel of A549 cells and H520 cells. Conversely, miR-744 mimics decreased paclitaxel-mediated inhibition of cell proliferation (Fig. 2E). The survival curves in the colony formation experiment demonstrated that agomiR-774 transfected A549 and H520 groups were more radioresistant 
than the corresponding control groups (Fig. 2F and S10 Table). Taken together, miR-744 enhanced the chemoresistance and radioresistance of lung cancer cells.

\section{C-FOS was directly targeted at transcriptional level and indirectly upregulated through the activation of MAPK pathway by miR-744 in NSCLC cells}

To gain insights into the molecular mechanism of miR-744 in the promotion of malignant phenotype of lung cancer cells, we analyzed the mRNAs differentially expressed before and after miR-744 downregulation by using genome-wide expression profile chip (GSE146601). A total of 11 differentially expressed mRNA were obtained, and all of them were down-regulated (S11 Table, screening criteria: Qvalue $\leq 0.05$, and fold change $\geq 1.8$ or fold change $\leq 0.55$ ). The results of qRT-PCR showed that only the mRNA level of C-FOS was changed more than twice in different transient antagomiR-744 or agomir-744 transfected cell lines (Fig. 3A and S4 Fig). Furthermore, we analyzed mRNA-Seq and miRNA-Seq data for NSCLC from TCGA and also revealed a positive correlation between the expression levels of miR-744 and CFOS $\left(r=0.2177 ; p=0035 ; \mathrm{Fig}\right.$. 3B). This positive regulation can not be explained by directly targeting the $3^{\prime}-$ untranslated region (3'UTR) of C-FOS, which could destabilize mRNA or inhibit translational efficiency [lacomino G, Siani A. Role of microRNAs in obesity and obesity-related diseases. Genes Nutr. 2017;12:23. doi: 10.1186/s12263-017-0577-z. eCollection 2017.]. Based on RNAhybrid software (http://bibiserv.techfak.uni-bielefeld.de/rnahybrid/), four putative miR-744 binding sites with lower minimum free energy (MFE) (Site 1, - 1195 to - 1227, Site 2, - 332 to - 358, Site 3, - 298 to - 323 and Site $4,-192$ to -221 ) were found in the promoter region of C-FOS gene (S5 Fig). We constructed three luciferase reporter vectors with different length of C-FOS gene promoter: C-FOS A promoter ( 1 to -500$)$ containing Site 1, Site 2, and Site 3, C-FOS B promoter (- 1 to -1300$)$, C-FOS C promoter (- 1 to -1900$)$, both containing all the putative sites. Ectopic expression of miR-744 significantly enhanced the luciferase activity of C-FOS A and C-FOS B reporter vectors, while the luciferase activity of C-FOS C was not significantly increased when compared with that of C-FOS B reporter vector (Fig. 3C). These results indicated that the binding sites of miR-744 to C-FOS promoter region might be between -1300 and - $1 \mathrm{bp}$ upstream to the transcription start site (TSS). Therefore, we further constructed mutant plasmids for the

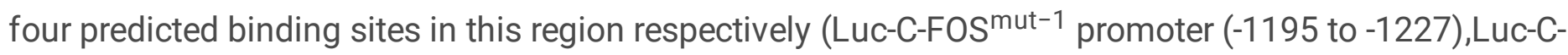
FOS $^{\text {mut-2 }}$ promoter (-332 to -358) [Luc-C-FOS ${ }^{\text {mut-3 }}$ promoter(-298 to -323) aLuc-C-FOS ${ }^{\text {mut-4 }}$ promoter (-192 to -221)), and co-transfected each mutant plasmid with agomiR-744 or agomir-NC into lung cancer cell lines to detect the luciferase activity. The results showed that the luciferase activity of promoter mutant plasmid Luc-C-FOS ${ }^{\text {mut-1 }}$ and LuC-C-FOS ${ }^{\text {mut-3 }}$ was significantly lower than that of C-FOS B promoter reporter vector. All of these confirmed that direct binding of miR-744 to the promoter region -1195 to -1227 and -298 to -323 bp upstream to the TSS led to the transcription activity of C-FOS increased (Fig. 3D). The degree of association between the expression of miR-744 and other 20503 genes was analyzed by calculating Pearson's coefficient and Spearman's rank correlation coefficient in 195 cases of NSCLC from TCGA database. 1155 genes with $P$ value less than 0.05 were selected for pathway annotation. The results showed that the expression of miR-744 was related to cell cycle regulation, MAPK pathway, WNT pathway, cytoskeleton regulation, chemokines, local adhesion, JAK/STAT and p53 pathways (S6 Fig). c-FOS was contained in MAPK pathway based on KEGG PATHWAY Database

Page 10/24 
(https://www.genome.jp/kegg/pathway.html). To validate the activation of MAPK pathway by miR-744, we detected the expression of GRB2, Raf1, total ERK1/2, ERK1/2 phosphorylation and c-FOS in A549, SPC-A-1, H1299, H520 cells transfected with agomiR-744 or agomir-NC by western blot. As Fig. 3E shown, a prominent increase in the expression of GRB2, Raf1, ERK1/2 phosphorylation, c-FOS was observed, except for the expression of total ERK1/2. Taken together, these results indicated an indirectly regulation of c-FOS by miR-744-mediated activation of MAPK pathway.

\section{C-FOS mediated the promotion of miR-744 on NSCLC cells migration, invasion and proliferation}

To evaluate whether malignant phenotype of lung cancer cells enhanced by miR-744 was mediated via CFOS, we performed co-transfection of si-C-FOS plasmid or si-control with agomiR-744 or agomir-NC respectively in A549, SPC-A-1, H1299 and H520 cells and the transfection effect was verified by qRT-PCR and western blot (Fig. 4A). It was noted that si-C-FOS partially or completely reversed the effect of agomiR744 on the migration, invasion and proliferation of lung cancer cells (Fig. 4B-4D and S7 Fig).

\section{miR-744 functions as a tumor promoter in lung cancer metastasis and growth in vivo.}

Antagomir has been reported to be able to interfere with microRNAs expression for a long time and been used in animal experiments[37]. To find out whether the expression of miR-744 could be continuously inhibited by antagomiR-744, we observed the interference effect of three concentrations of antagomiR-744 for 27 days and select a concentration of $125 \mathrm{~nm}$ for the further study (Fig. 5A). We also developed Lv-miR744 to stably overexpress miR-744 in lung cancer cells for in vivo study (Fig. 5B). The growth promoting effect of miR-744 was confirmed as expected in xenograft tumor models. Wheras, tumor growth was significantly inhibited in antagomiR-744 group compared to antagomir-NC. (Fig. 5C and 5D). More prominently, significant enhancement of lung metastasis was also observed by bioluminescent imaging, which was further verified by H\&E staining (Fig. 5E-5H) Accordingly, the expression of C-FOS presented the same trend as that of miR-744 (S8 Fig). Collectively, these data further demonstrated that miR-744 played critical role in the development of NSCLC growth and metastasis, and targeting miR-744 with antagomiR744 might serve as an effective therapeutic approach to attenuate NSCLC progression.

\section{Discussion}

It is well known that miRNAs have emerged as key mediators of tumorigenesis and development, as they broadly participate in cellular processes, including invasion, proliferation, senescence, extracellular matrix (ECM) synthesis and death [38-40]. MiR-744 was one of the microRNAs that changed after the interference of a metastasis related gene in NSCLC cells, which was the first time that miR-744 caught our attention[3]. Up to now, it has been observed that miR-744 was a promising tumor molecular marker in some tumor tissues or serum (Table 1), including chronic lymphocytic leukemia[8], hepatocellular carcinoma[12], osarcoteosma[18] and gastric cancer[31]. However, there is still no study on the expression of miR-744 in lung cancer. We first found that the expression of miR-744 in NSCLC tissues was significantly higher than that in paracancerous tissues. To make the clinical significance of miR-744 more clear, we used different methods to detect the expression of miR-744 in two NSCLC cohorts. It was confirmed that the high expression of miR-744 was significantly related to lymph node metastasis and poor prognosis of NSCLC, 
and was an independent prognostic molecular marker of NSCLC. This is comparable to findings in the studies on pancreatic cancer[19-21], prostate cancer[23,24] and nasopharyngeal carcinoma[4, 36]. All of these suggested that miR-744 might play an important role in the process of NSCLC progression and metastasis, and need to be further studied.

Although miR-744 has been mentioned in a few NSCLC studies, they were limited to the indirect description of miR-744 expression on the cell level[ $[15,16]$. Only two studies preliminarily revealed that miR-744 was down regulated in EGFR TKI primary resistant patients' plasma[17] and might function as a tumor suppressor in vitro[14]. In the current study, we provided evidence at both the cellular and animal levels that miR-744 acted as an oncogene and promoted the proliferation, migration, invasion and metastasis of NSCLC cells in vitro and in vivo, which was consistent with the findings in previous clinical specimen-based study. At present, there are limited studies about the role of miR-744 in chemosensitivity[9, 11, 20, 29, 33] and radiosensitivity, and the reported influence of miR-744 on the sensitivity of cancer cells to different drugs was quite different $[9,11]$. Our study confirmed that miR-744 could reduce the sensitivity of lung cancer cells to paclitaxel, a commonly used chemotherapy drug in clinical practice, and miR-744 also increased the resistance of cells to radiotherapy.

The role of miRNAs partially relied on their regulation of the expression of many cancer-related genes through post-transcriptional repression[40], and they silenced genes through pairing between limited bases in the seed region and complementary sequences in target mRNA 3'-UTR. At present, there are reports that miRNAs could target 5'-UTRs[41], coding regions[42], promoters[43], or gene terminal downstream sequences[44] to silence gene expression, which revealed the possibility of multi-mode effect of miRNAsmediated gene regulation. However, the regulatory mechanism of miR-744 in lung cancer remains to be elucidated.

c-FOS, as a major component of activator protein (AP)-1 complex, has been involved in cell differentiation, proliferation, angiogenesis, invasion, and metastasis[45, 46]. Here, we found that c-FOS was an important target gene positively regulated by miR-744, which mediated the promotion of miR-744 on the malignant phenotype of NSCLC cells. This phenomenon has aroused our research interest, because this result could not be explained by the classical regulatory mechanism of targeting 3'-UTR. In our previous study, we also proposed and confirmed that ARHGAP5, as a critical proto-oncogene, is regulated at the transcription level by miR-774 through direct binding with its promoter region, and contributed to the promotion of miR744 on NPC invasion and migration[4]. In this study, we also confirmed the direct binding sites between miR-744 and C-FOS promoter by luciferase reporter gene analysis. In addition, high expression of miR-744 could activate MAPK signaling pathway, and C-FOS is just the downstream gene of this pathway. This newly disclosed miR-744/MAPK/C-FOS axis further revealed the mechanism of NSCLC progression (Fig. 6).

Our previous studies have confirmed that c-Jun could regulate miR-744 at the transcription level in both NPC and lung cancer cells[47], because C-JUN can combine with C-FOS to form AP-1 early response transcription factor[48, 49], so whether there is a positive feedback between miR-744/C-FOS axis and C$\mathrm{JUN} / \mathrm{miR}-744$ axis needs further study. In conclusion, we presented here that miR-744 could directly and indirectly up-regulate the expression of C-FOS, and then promoted the malignant phenotype of NSCLC cells.

Page 12/24 
The newly identified miR-744/C-FOS axis provided new insights into the progression of lung cancer. At the same time, it added new contents for understanding the biological function of miR-744 gene and its role in tumorigenesis and development, and also provided potential targets for prognosis prediction and drugs intervention in NSCLC.

\section{Abbreviations}

MiR-744: microRNA-744;

SCC: squamous carcinoma;

Cl: Confidence interval;

HR: Hazard ratio;

NC: Negative control;

RT-qPCR: reverse transcriptase-quantitative real time PCR;

WT: Wild type

CCK-8: Cell counting kit-8

ISH: In situ hybridization

KEGG: Kyoto Encyclopedia of Genes and Genomes;

\section{Declarations}

\section{Availability of data and materials}

Datasets used and/or analyzed during the current study are available from

\section{Ethics approval and consent to participate}

The present study was approved by the Medical Ethics Committee of Southern Medical University and Experimental animal ethics committee of Southern Medical University.

\section{Consent for publication}

Not applicable.

\section{Competing interests}

The authors declare that they have no competing interests.

\section{Funding}


This work was supported by the National Natural Science Foundation of China (http://www.nsfc.gov.cn/) (81572279, 81972853), University Excellent Young Teachers Program of Guangdong Province (http://edu.gd.gov.cn/) (Yq2013040), and Clinical Research Startup Program of Southern Medical University by High-level University Construction Funding of Guangdong Provincial Department of Education (http://www.smu.edu.cn/) (LC2019ZD009).

\section{Authors' contributions}

ZXX designed experiments, analyzed data and wrote the paper; LSB, LN performed experiments and analyzed the data. All authors read and approved the final manuscript.

\section{Acknowledgements}

Not applicable.

\section{References}

1. Xie RL, Jang YJ, Xing L, Zhang BF, Wang FZ, Cui PF, Cho MH, Jiang HL. A novel potential biocompatible hyperbranched polyspermine for efficient lung cancer gene therapy. Int J Pharm. 2015;478:19-30.

2. Ma Y, Zhang P, Yang J, Liu Z, Yang Z, Qin H. Candidate microRNA biomarkers in human colorectal cancer: systematic review profiling studies and experimental validation. Int J Cancer. 2012;130:207787.

3. Zhu X, Zhang X, Wang H, Song Q, Zhang G, Yang L, Geng J, Li X, Yuan Y, Chen L. MTA1 gene silencing inhibits invasion and alters the microRNA expression profile of human lung cancer cells. Oncol Rep. 2012;28:218-24.

4. Fang Y, Zhu X, Wang J, Li N, Li D, Sakib N, Sha Z, Song W. MiR-744 functions as a proto-oncogene in nasopharyngeal carcinoma progression and metastasis via transcriptional control of ARHGAP5. Oncotarget. 2015;6:13164-75.

5. Milde-Langosch $\mathrm{K}$. The Fos family of transcription factors and their role in tumourigenesis. Eur $\mathrm{J}$ Cancer. 2005;41:2449-61.

6. Donnem T, Eklo K, Berg T, Sorbye SW, Lonvik K, Al-Saad S, Al-Shibli K, Andersen S, Stenvold H, Bremnes RM, Busund LT. Prognostic impact of MiR-155 in non-small cell lung cancer evaluated by in situ hybridization. J Transl Med. 2011;9:6.

7. Sass HCR, Hansen M, Borup R, Nielsen FC, Caye-Thomasen P. Tumor miRNA expression profile is related to vestibular schwannoma growth rate. Acta Neurochir (Wien) 2020.

8. Kaur G, Ruhela V. RNA-Seq profiling of deregulated miRs in CLL and their impact on clinical outcome. 2020, 10:6.

9. Zhou Y, He A, Zhang L, Yi G: MiR-744 mediates the Oxaliplatin chemoresistance in colorectal cancer through inhibiting BIN1. Neoplasma 2019. 
10. Shen J, Li M. MicroRNA-744 inhibits cellular proliferation and invasion of colorectal cancer by directly targeting oncogene Notch1. Oncol Res 2018.

11. Wang G, Zhao W, Wang H, Qiu G, Jiang Z, Wei G, Li X. Exosomal MiR-744 Inhibits Proliferation and Sorafenib Chemoresistance in Hepatocellular Carcinoma by Targeting PAX2. Med Sci Monit. 2019;25:7209-17.

12. Tan YL, Bai ZG, Zou WL, Ma XM, Wang TT, Guo W, Liu J, Li JS, Jie Y, Zang YJ, Zhang ZT. miR-744 is a potential prognostic marker in patients with hepatocellular carcinoma. Clin Res Hepatol Gastroenterol. 2015;39:359-65.

13. Lin F, Ding R, Zheng S, Xing D, Hong W, Zhou Z, Shen J. Decrease expression of microRNA-744 promotes cell proliferation by targeting c-Myc in human hepatocellular carcinoma. Cancer Cell Int. 2014;14:58.

14. Chen S, Shi F, Zhang W, Zhou Y, Huang J. miR-744-5p Inhibits Non-Small Cell Lung Cancer Proliferation and Invasion by Directly Targeting PAX2. 2019, 18:1533033819876913.

15. Wang J, Cai H, Dai Z, Wang G. Down-regulation of IncRNA XIST inhibits cell proliferation via regulating miR-744/RING1 axis in non-small cell lung cancer. 2019, 133:1567-1579.

16. Sui Y, Lin G, Zheng Y, Huang W. LncRNA MAFG-AS1 boosts the proliferation of lung adenocarcinoma cells via regulating miR-744-5p/MAFG axis. Eur J Pharmacol. 2019;859:172465.

17. Ma Y, Pan X, Xu P, Mi Y, Wang W, Wu X, He Q, Liu X, Tang W, An HX. Plasma microRNA alterations between EGFR-activating mutational NSCLC patients with and without primary resistance to TKI. Oncotarget. 2017;8:88529-36.

18. Sun L, Liu M, Luan S, Shi Y, Wang Q. MicroRNA-744 promotes carcinogenesis in osteosarcoma through targeting LATS2. Oncol Lett. 2019;18:2523-9.

19. Zhou J, Hui X, Mao Y, Fan L. Identification of novel genes associated with a poor prognosis in pancreatic ductal adenocarcinoma via a bioinformatics analysis. 2019, 39.

20. Miyamae M, Komatsu S, Ichikawa D, Kawaguchi T, Hirajima S, Okajima W, Ohashi T, Imamura T, Konishi $\mathrm{H}$, Shiozaki A, et al. Plasma microRNA profiles: identification of miR-744 as a novel diagnostic and prognostic biomarker in pancreatic cancer. Br J Cancer. 2015;113:1467-76.

21. Zhou W, Li Y, Gou S, Xiong J, Wu H, Wang C, Yan H, Liu T. MiR-744 increases tumorigenicity of pancreatic cancer by activating Wnt/beta-catenin pathway. Oncotarget. 2015;6:37557-69.

22. Krokker L, Nyiro G, Reiniger L, Darvasi O, Szucs N, Czirjak S, Toth M, Igaz P, Patocs A, Butz H. Differentially Expressed miRNAs Influence Metabolic Processes in Pituitary Oncocytoma. 2019, 44:2360-2371.

23. Zhang M, Li H, Zhang Y, Li H. Oncogenic miR-744 promotes prostate cancer growth through direct targeting of LKB1. Oncol Lett. 2019;17:2257-65.

24. Guan H, Liu C, Fang F, Huang Y, Tao T, Ling Z, You Z, Han X, Chen S, Xu B, Chen M. MicroRNA-744 promotes prostate cancer progression through aberrantly activating Wnt/beta-catenin signaling. Oncotarget. 2017;8:14693-707. 
25. Huang V, Place RF, Portnoy V, Wang J, Qi Z, Jia Z, Yu A, Shuman M, Yu J, Li LC. Upregulation of Cyclin B1 by miRNA and its implications in cancer. Nucleic Acids Res. 2012;40:1695-707.

26. Deng Y, Li Y, Fang Q, Luo H, Zhu G. microRNA-744 is downregulated in glioblastoma and inhibits the aggressive behaviors by directly targeting NOB1. Am J Cancer Res. 2018;8:2238-53.

27. Hubner M, Hinske CL, Effinger D, Wu T, Thon N, Kreth FW, Kreth S. Intronic miR-744 Inhibits Glioblastoma Migration by Functionally Antagonizing Its Host Gene MAP2K4. Cancers (Basel) 2018, 10.

28. Li C, Jia L, Yu Y, Jin L. Lactic acid induced microRNA-744 enhances motility of SiHa cervical cancer cells through targeting ARHGAP5. Chem Biol Interact. 2019;298:86-95.

29. Phuah NH, In LL, Azmi MN, Ibrahim H, Awang K, Nagoor NH. Alterations of microRNA expression patterns in human cervical carcinoma cells (Ca Ski) toward 1'S-1'-acetoxychavicol acetate and cisplatin. Reprod Sci. 2013;20:567-78.

30. Liu J, Wei Y, Li S, Li Y, Liu H, Liu J, Zhu X. MicroRNA-744 promotes cell apoptosis via targeting B cell lymphoma-2 in gastric cancer cell line SGC-7901. Exp Ther Med. 2018;16:3611-6.

31. Song MY, Pan KF, Su HJ, Zhang L, Ma JL, Li JY, Yuasa Y, Kang D, Kim YS, You WC. Identification of serum microRNAs as novel non-invasive biomarkers for early detection of gastric cancer. PLoS One. 2012;7:e33608.

32. Kleemann M, Schneider H, Unger K, Sander P, Schneider EM, Fischer-Posovszky P, Handrick R, Otte K. MiR-744-5p inducing cell death by directly targeting HNRNPC and NFIX in ovarian cancer cells. Sci Rep. 2018;8:9020.

33. Chen X, Lu P, Wang DD, Yang SJ, Wu Y, Shen HY, Zhong SL, Zhao JH, Tang JH. The role of miRNAs in drug resistance and prognosis of breast cancer formalin-fixed paraffin-embedded tissues. Gene. 2016;595:221-6.

34. Leivonen SK, Sahlberg KK, Makela R, Due EU, Kallioniemi O, Borresen-Dale AL, Perala M. Highthroughput screens identify microRNAs essential for HER2 positive breast cancer cell growth. Mol Oncol. 2014;8:93-104.

35. Vislovukh A, Kratassiouk G, Porto E, Gralievska N, Beldiman C, Pinna G, El'skaya A, Harel-Bellan A, Negrutskii B, Groisman I. Proto-oncogenic isoform A2 of eukaryotic translation elongation factor eEF1 is a target of miR-663 and miR-744. Br J Cancer. 2013;108:2304-11.

36. Yu Q, Zhang F, Du Z, Xiang Y. Up-regulation of serum miR-744 predicts poor prognosis in patients with nasopharyngeal carcinoma. Int J Clin Exp Med. 2015;8:13296-302.

37. Cui J, Chu Q, Xu T. miR-122 involved in the regulation of toll-like receptor signaling pathway after Vibrio anguillarum infection by targeting TLR14 in miiuy croaker. Fish Shellfish Immunol. 2016;58:67-72.

38. Le LT, Cazares O, Mouw JK, Chatterjee S, Macias H, Moran A, Ramos J, Keely PJ, Weaver VM, Hinck L. Loss of miR-203 regulates cell shape and matrix adhesion through ROBO1/Rac/FAK in response to stiffness. J Cell Biol. 2016;212:707-19.

39. Wu L, Wang Q, Guo F, Ma X, Ji H, Liu F, Zhao Y, Qin G. MicroRNA-27a Induces Mesangial Cell Injury by Targeting of PPARgamma, and its In Vivo Knockdown Prevents Progression of Diabetic Nephropathy. 
Sci Rep. 2016;6:26072.

40. Wang Q, Huang Z, Guo W, Ni S, Xiao X, Wang L, Huang D, Tan C, Xu Q, Zha R, et al. microRNA-202-3p inhibits cell proliferation by targeting ADP-ribosylation factor-like 5A in human colorectal carcinoma. Clin Cancer Res. 2014;20:1146-57.

41. Lytle JR, Yario TA, Steitz JA. Target mRNAs are repressed as efficiently by microRNA-binding sites in the 5' UTR as in the 3' UTR. Proc Natl Acad Sci U S A. 2007;104:9667-72.

42. Tay Y, Zhang J, Thomson AM, Lim B, Rigoutsos I. MicroRNAs to Nanog, Oct4 and Sox2 coding regions modulate embryonic stem cell differentiation. Nature. 2008;455:1124-8.

43. Miao L, Yao H, Li C, Pu M, Yao X, Yang H, Qi X, Ren J, Wang Y. A dual inhibition: microRNA-552 suppresses both transcription and translation of cytochrome P450 2E1. Biochim Biophys Acta. 2016;1859:650-62.

44. Younger ST, Corey DR. Transcriptional regulation by miRNA mimics that target sequences downstream of gene termini. Mol Biosyst. 2011;7:2383-8.

45. Liu ZG, Jiang G, Tang J, Wang H, Feng G, Chen F, Tu Z, Liu G, Zhao Y, Peng MJ, et al. c-Fos overexpression promotes radioresistance and predicts poor prognosis in malignant glioma. Oncotarget. 2016;7:65946-56.

46. Muhammad N, Bhattacharya S, Steele R, Phillips N, Ray RB. Involvement of c-Fos in the Promotion of Cancer Stem-like Cell Properties in Head and Neck Squamous Cell Carcinoma. Clin Cancer Res. 2017;23:3120-8.

47. Sha Z, Zhu X, Li N, Li Y, Li D. Proto-oncogenic miR-744 is upregulated by transcription factor c-Jun via a promoter activation mechanism. Oncotarget. 2016;7:64977-86.

48. Karamouzis MV, Konstantinopoulos PA, Papavassiliou AG. The activator protein-1 transcription factor in respiratory epithelium carcinogenesis. Mol Cancer Res. 2007;5:109-20.

49. Li Q, Liu G, Shao D, Wang J, Yuan H, Chen T, Zhai R, Ni W, Tai G. Mucin1 mediates autocrine transforming growth factor beta signaling through activating the c-Jun N-terminal kinase/activator protein 1 pathway in human hepatocellular carcinoma cells. Int J Biochem Cell Biol. 2015;59:116-25.

\section{Figures}



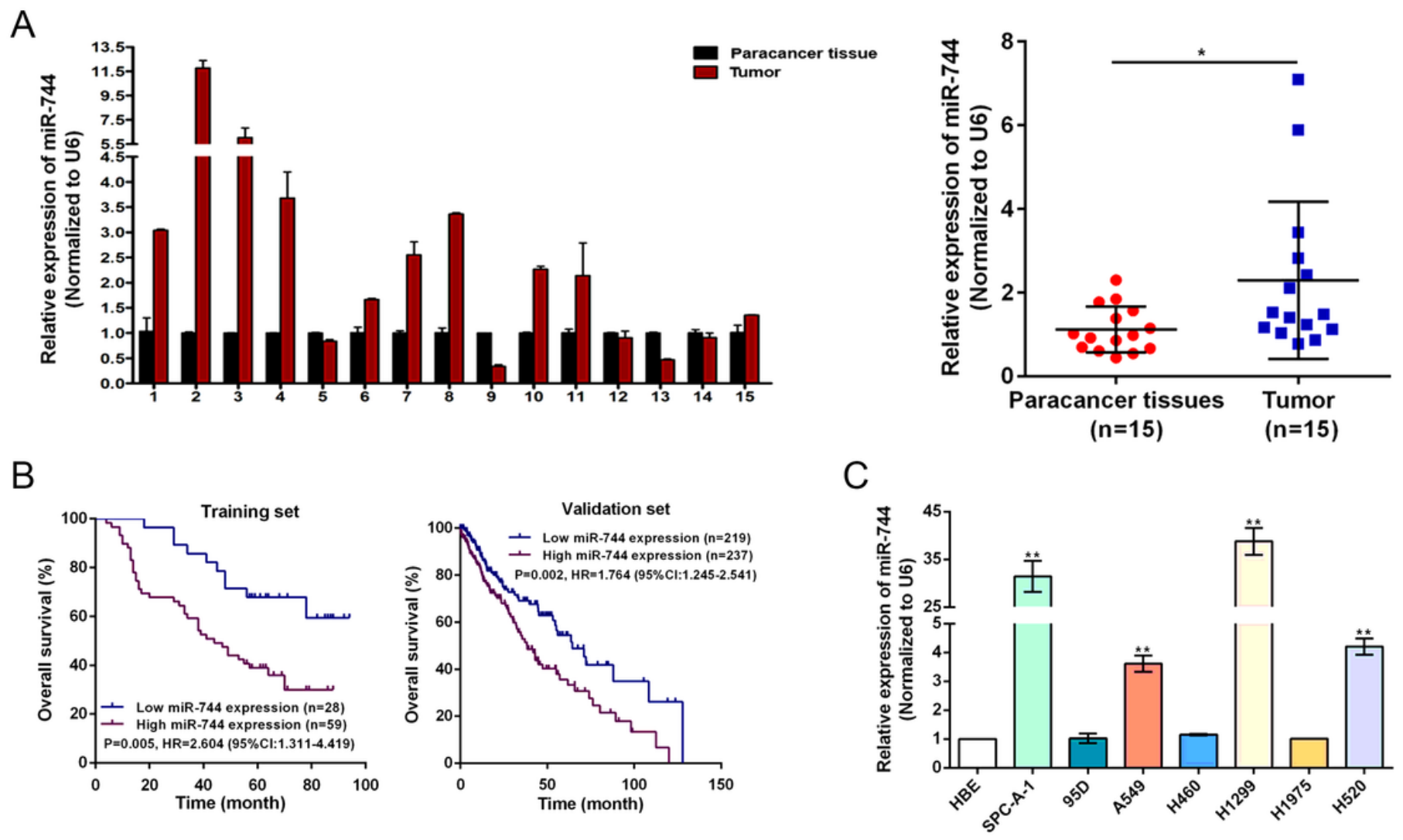

\section{Figure 1}

MiR-744 is upregulated in human NSCLC tissues and cell lines and associated with poor prognosis. (A) MiR-744 expression in NSCLC and adjacent nonneoplastic lung tissues. (B) Kaplan-Meier survival analysis of overall survival in NSCLC training cohort (left, $n=87$ ) and validation cohort (right, $n=456$ ). (C) RT-PCR analysis of miR-744 levels in NSCLC cell lines and immortalized bronchial epithelial cell HBE. 
A

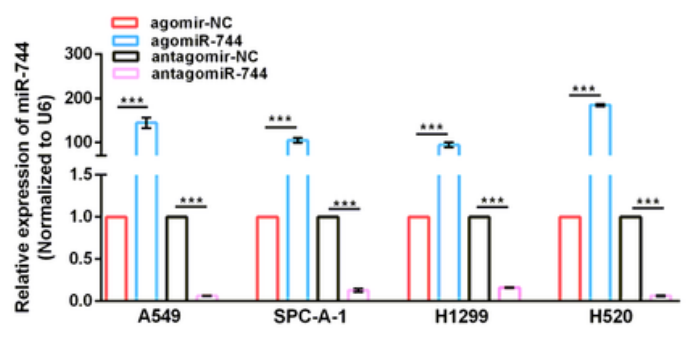

C
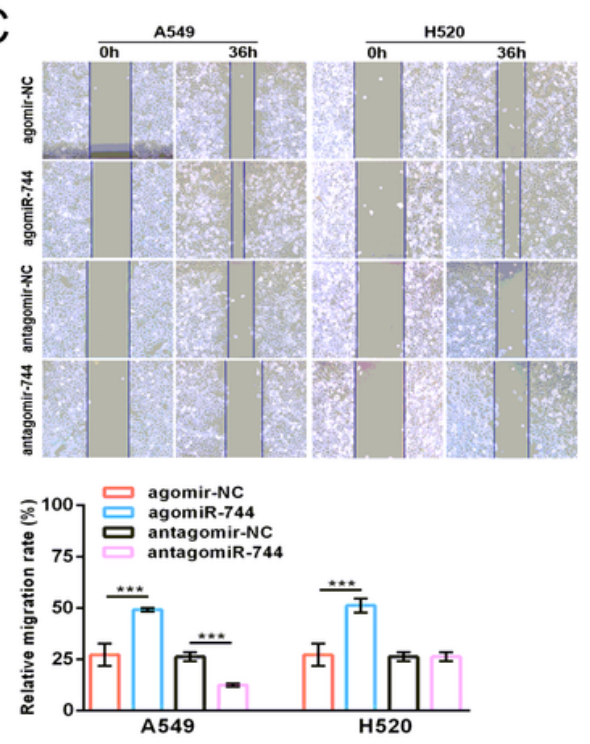

E

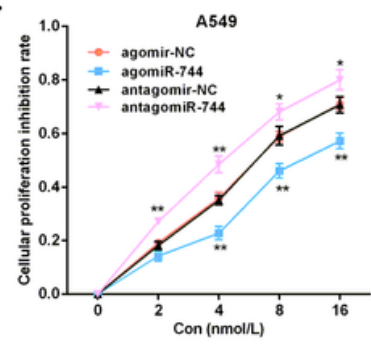

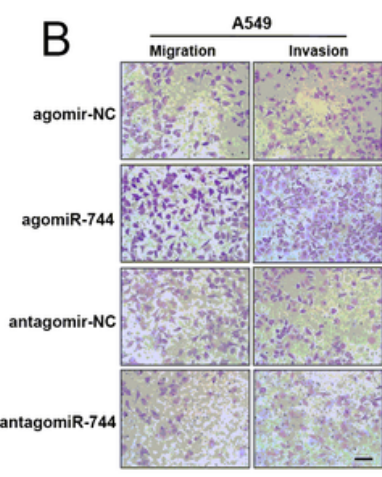
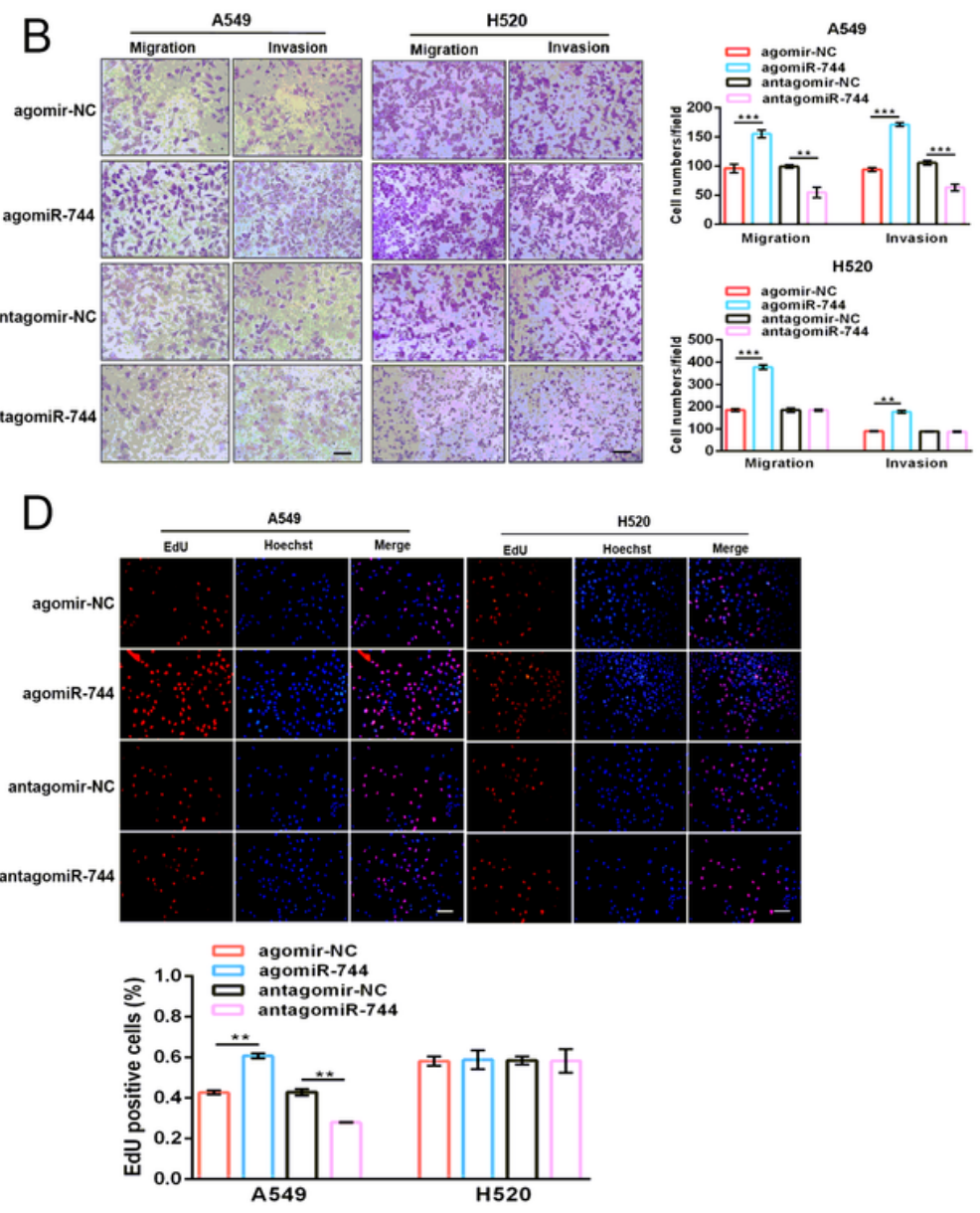

$\mathrm{F}$
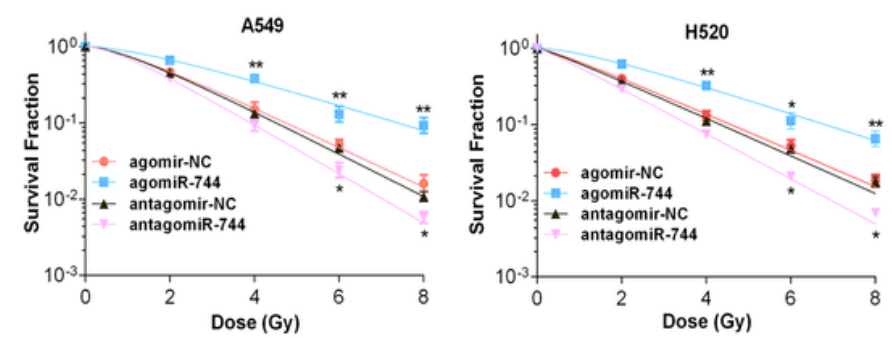

\section{Figure 2}

MiR-744 contributes to NSCLC cells migration, invasion and proliferation in vitro. (A) The transfection efficacies of agomiR-744 and antagomiR-744 in NSCLC cells were detected through RT-qPCR. (B) Representative images (left) of Transwell and Boyden assays in transfected NSCLC cells and quantification (right) of migration and invasion ability. Scale bar, $100 \mu \mathrm{m}$. (C) Wound healing assay in NSCLC cells.

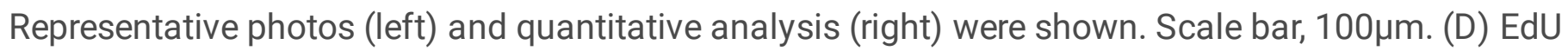
detection of the proliferation ability under the treatment of agomiR-744 or antagomiR-744. Scale bar, $100 \mu \mathrm{m}$. (E) Impact of miR-744 on the proliferation inhibitory effect of paclitaxel determined by CCK8 
assay. (F) Survival fraction of NSCLC cells with miR-744 overexpression or down-expression following

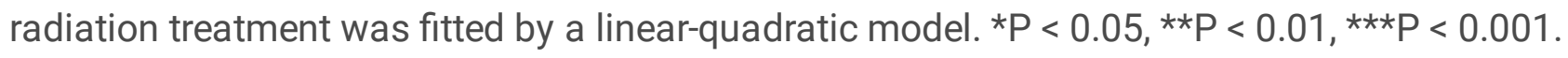

A

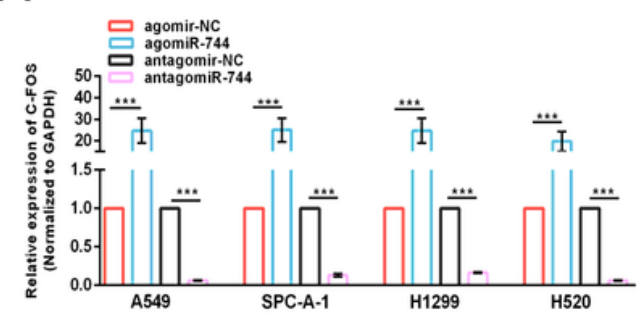

D

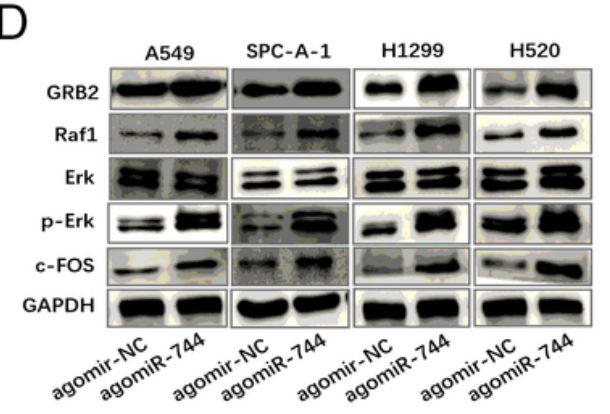

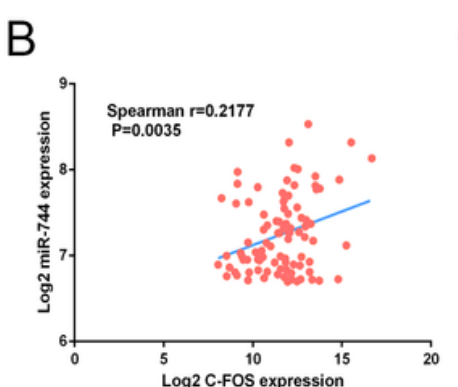

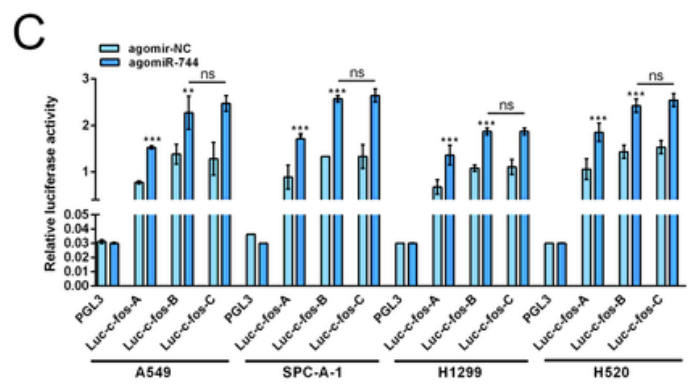

E

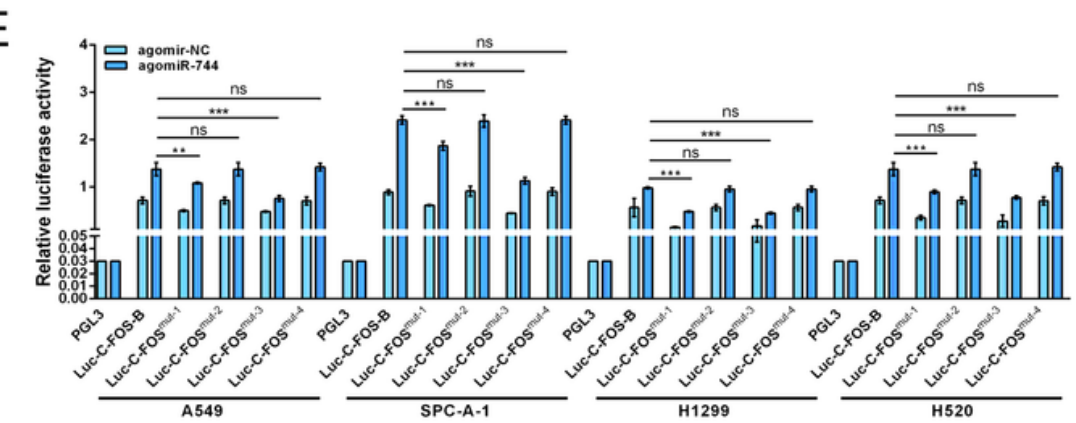

\section{Figure 3}

C-FOS was directly and indirectly upregulated by miR-744 in NSCLC cells. (A) RT-PCR analysis of C-FOS expression in NSCLC cells transfected with agomiR-744, antagomiR-744, or controls for 48 h. (B) A positive correlation between high level (top 11\%) of miR-744 and C-FOS mRNA expression was presented in NSCLC samples ( $n=94)$ from TCGA. (C) Luciferase activity of three different length of C-FOS promoter-reporter constructs and vector control in the presence of agomiR-744 or agomir-NC was analyzed in NSCLC cells. (D) The luciferase activity of reporter vectors containing wild type or mutations of the binding sites in the promoter of C-FOS gene was detected after the co-transfection with agomiR-744 or agomir-NC in NSCLC cells for $48 \mathrm{~h}$. (E) Enforced expression of miR-744 effectively activated MAPK pathway assessed by Western blot analysis of GRB2, Raf-1, total ERK1/2, ERK1/2 phosphorylation, c-FOS in NSCLC cells. *P < $0.05, \star * P<0.01, * \star \star P<0.001$ compared to controls. ns, non-significant. 
A
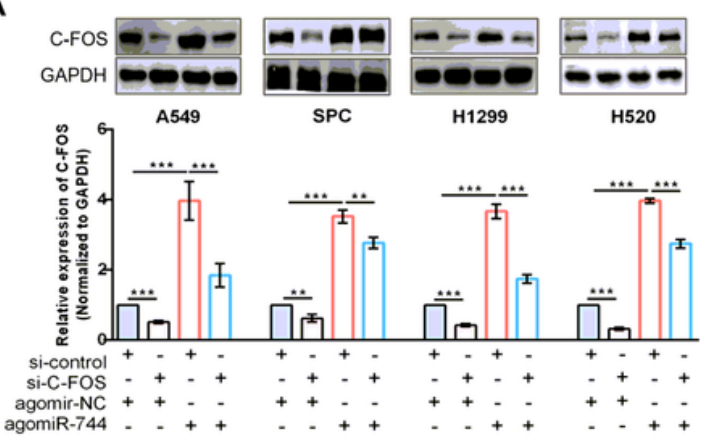

C
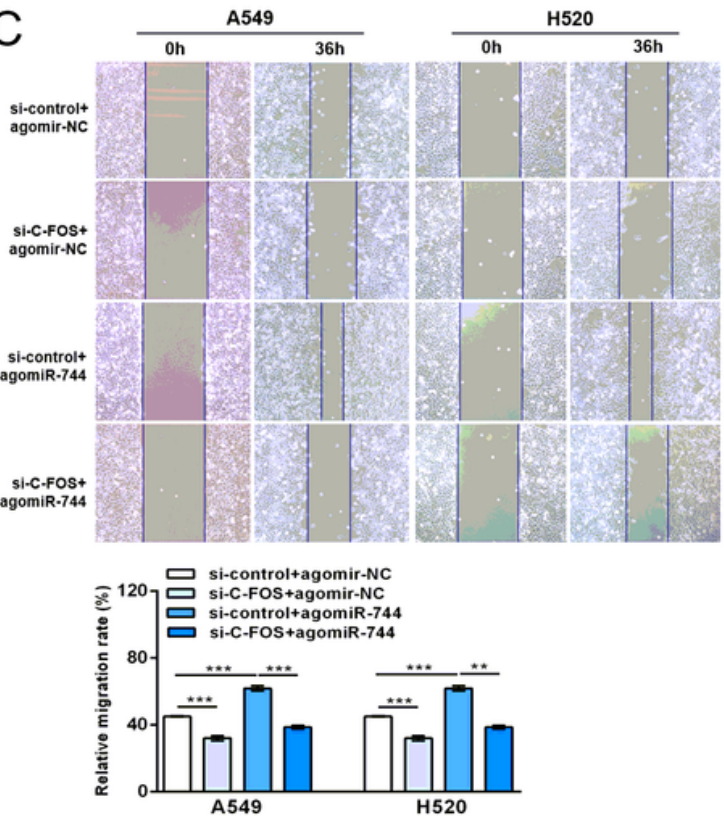

B
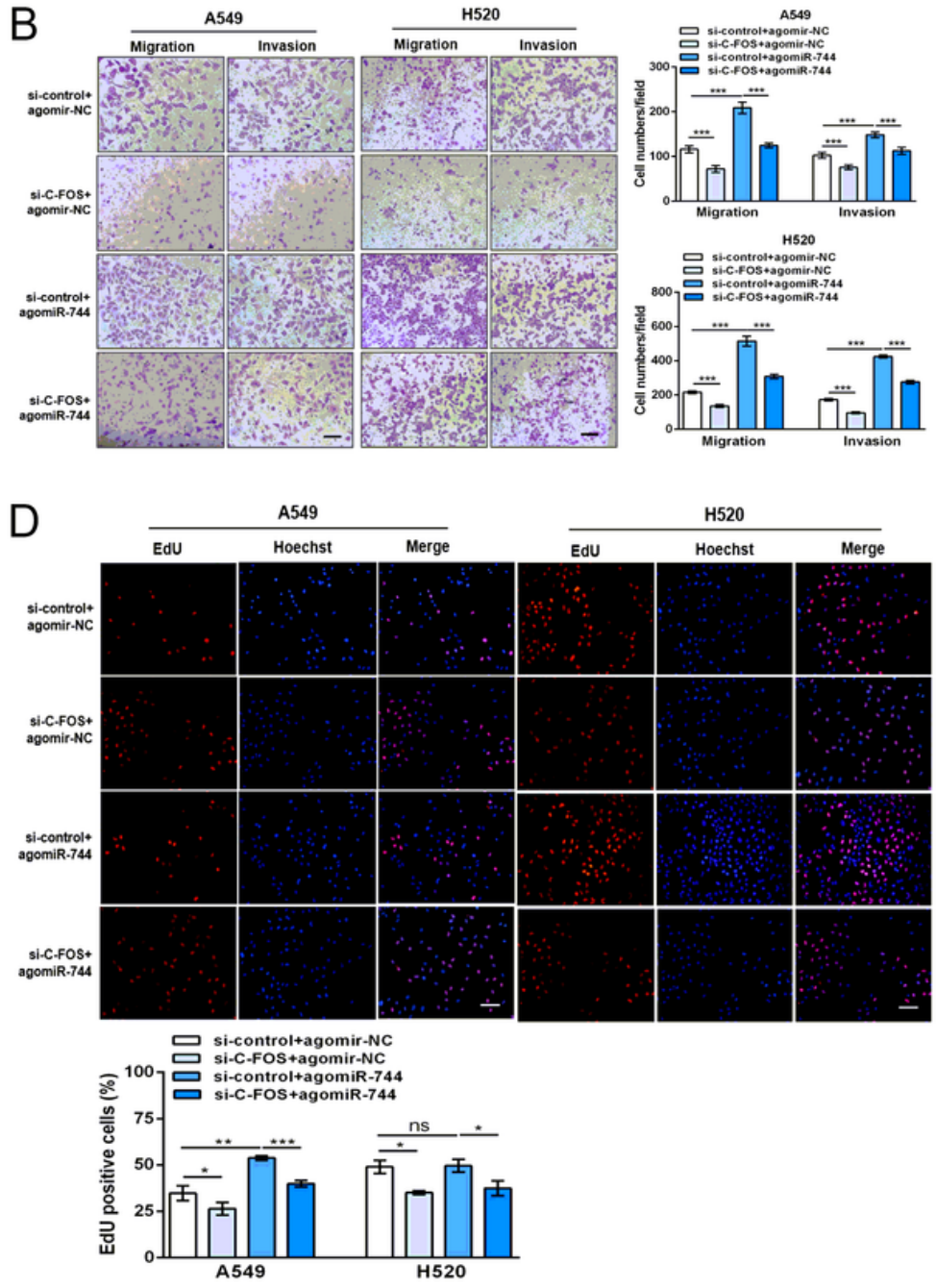

\section{Figure 4}

Knockdown of C-FOS reversed the ectopically overexpressed miR-744-induced enhancement of migration, invasion and proliferation of NSCLC cells. (A) C-FOS mRNA and protein expression level in NSCLC cells cotransfected with C-FOS-silencing plasmid and agomiR-744 or controls. (B) Transwell assay (C) Woundhealing assay and (D) Edu assay were performed to confirm that silence of C-FOS abrogated the promotion of cell migration, invasion and proliferation associated with the enforced expression of miR-744. ${ }^{*} \mathrm{P}<0.05$, $\star * P<0.01,{ }^{* * *} P<0.001$. ns, non-significant. 

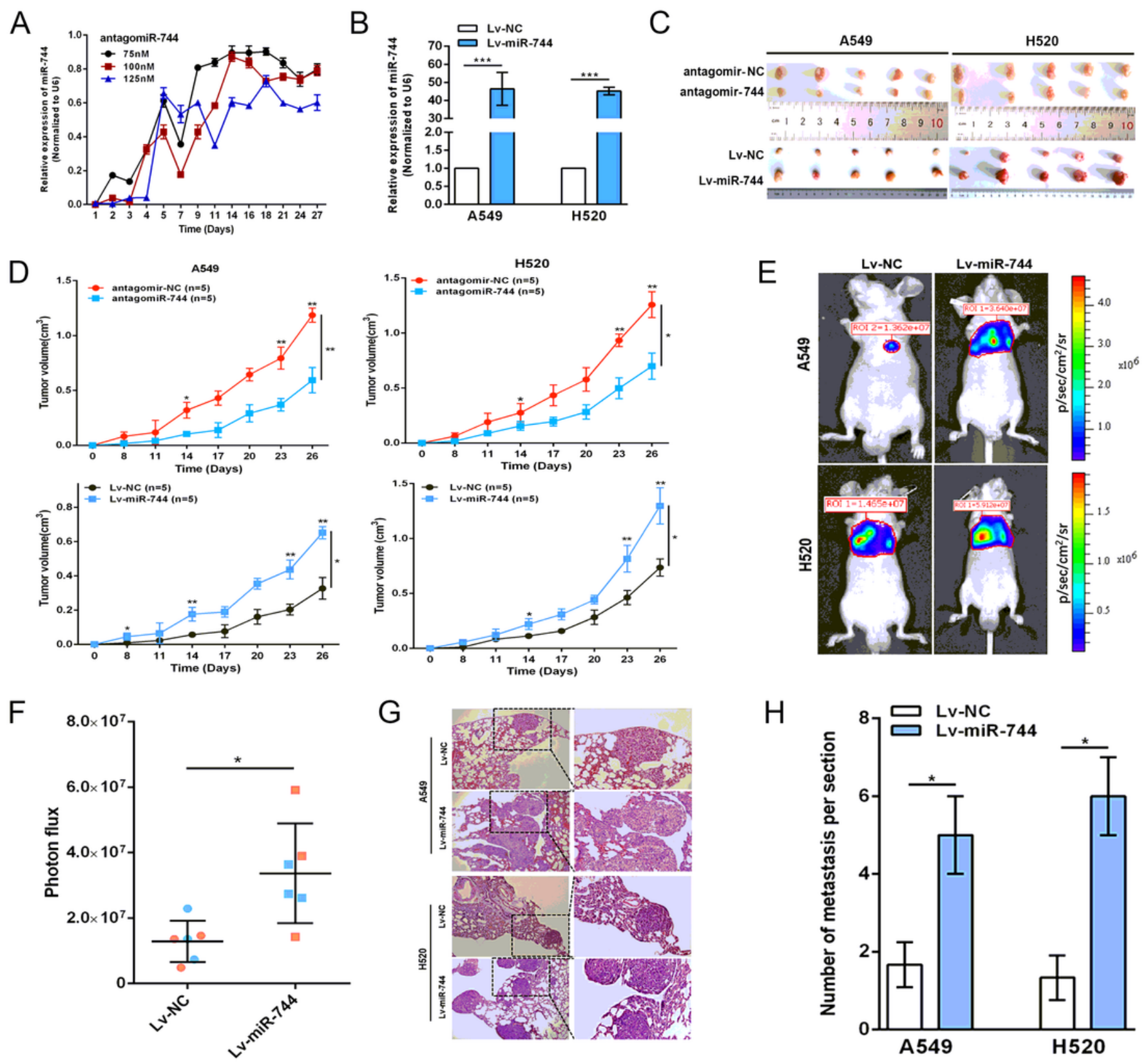

\section{Figure 5}

MiR-744 functions as a tumor promoter in NSCLC cells growth and metastasis in vivo. (A) Continuously inhibitory efficiency of different concentration of antagomiR-744 was monitored by RT-PCR analysis in A549 cells. (B) Transfection efficiency of lentivirus vector of miR-744 was validated in NSCLC cells by RTPCR. (C) Subcutaneous tumor growth in mouse xenografts injected with NSCLC cells stably knockdown or overexpressing miR-744 or control cells. (D) Time-dependent tumor growth curves of the different treatment groups. Tumor volume was measured at different time points and calculated with the following formula: $V$ $=(\mathrm{L} \times \mathrm{W} 2) / 2, \mathrm{~V}$, volume $(\mathrm{mm} 3) ; \mathrm{L}$, biggest diameter $(\mathrm{mm}) ; \mathrm{W}$, smallest diameter $(\mathrm{mm}) .(\mathrm{E})$ Representative bioluminescence images (BLI) of mouse lung at 30 days after tail vein injection of indicated cells. $(F)$ 
Statistical analysis of lung area photon flux $(n=6)$. (G) Representative microscopic images of H\&E staining of mouse lung from each group at 30 days after injection of cells stably transfected with Lv-miR-744 or empty vector. $(H)$ The average of lung metastasis index in each group of mice $(n=5)$. Lung metastasis index was calculated as follows: metastatic tumor areas/total lung areas. ${ }^{*} P<0.05,{ }^{\star \star} P<0.01, \star \star \star P<$ 0.001 compared to controls.

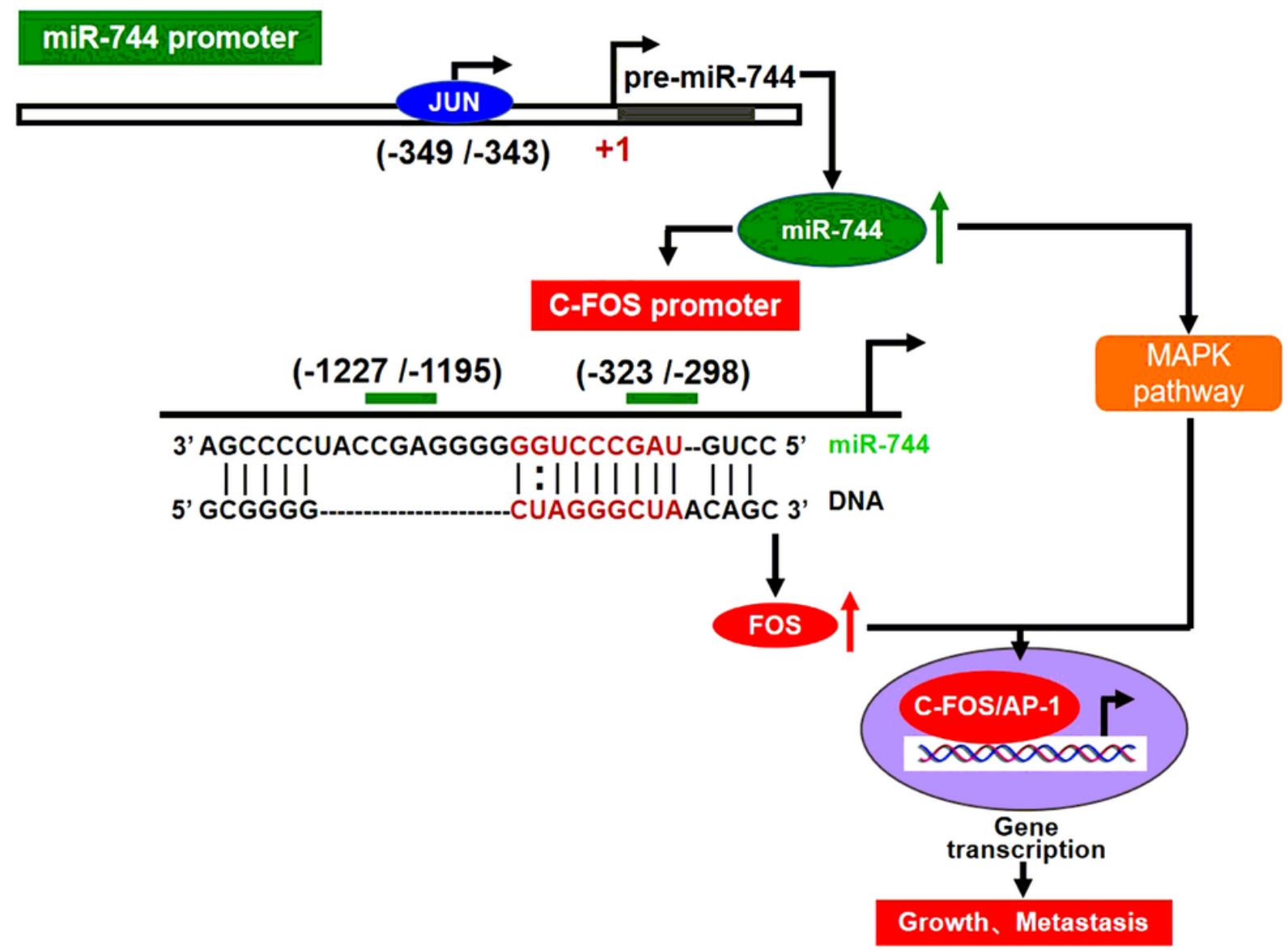

Figure 6

Schematic diagram of miR-744/MAPK/C-FOS axis mediating NSCLC progression. miR-744 positively regulated C-FOS by directly binding to the promoter of C-FOS and also indirectly upregulate C-FOS protein by activating MAPK pathway, thus mediating the growth and metastasis of NSCLC.

\section{Supplementary Files}

This is a list of supplementary files associated with this preprint. Click to download.

- S1Table.docx

- S2Table.docx 
- S3Table.docx

- S4Table.docx

- S5Table.docx

- S6Table.docx

- S7Table.docx

- S8Table.docx

- S9Table.docx

- S10Table.docx

- S11Table.docx

- Suppl.Fig.1.tif

- Suppl.Fig.2.tif

- Suppl.Fig.3.tif

- Suppl.Fig.4.tif

- Suppl.Fig.5.tif

- Suppl.Fig.6.tif

- Suppl.Fig.7.tif

- Suppl.Fig.8.tif 